\title{
Some reflections about diverse responses to the COVID-19 pandemic
}

\author{
Hersh Shefrin ${ }^{1}$ (iD
}

Received: 13 July 2020 / Accepted: 17 July 2020 / Published online: 25 July 2020

(c) Springer-Verlag GmbH Germany, part of Springer Nature 2020

\begin{abstract}
This paper discusses the wide diversity of responses by different countries to COVID-19.
\end{abstract}

Keywords Pandemic · Diverse responses · Darwinian principles

Policy reactions across the globe to the emergence of the COVID-19 pandemic have been diverse, a phenomenon I find striking. Why such diversity in responses by China, the United States, the United Kingdom, South Korea, Italy, and Germany?

Diversity in national policy responses reflects diversity among individuals, and can be seen among academics as well. Below, I offer some reflections on what people thought about COVID-19, as it first developed.

In my own case, I remember becoming aware around the turn of the year that a novel coronavirus had emerged in Wuhan, China, that a Chinese physician had warned his colleagues that the virus might give rise to a possible epidemic, and that local officials had sought to silence his warning. At the time, I was certainly aware of the possibility that an epidemic might occur in China, and spread outside of China. I recall thinking that the probability of an epidemic within China, caused by the new coronavirus epidemic, was nontrivial. However, based on my recollections of past outbreaks, such as SARS, MERS, and Ebola, I am quite certain that I did not initially attach high probability that an outbreak in China would evolve into a pandemic.

I began to revise my beliefs about an epidemic in China in the second half of January, as news about rising deaths in Wuhan began to trickle out. I began to revise my views about the epidemic becoming a pandemic in the third week of February, as the media began to report on outbreaks on cruise ships, the U.S. stock market fell sharply in response, and epidemiologists from the World Health Organization issued

Hersh Shefrin

hshefrin@scu.edu

1 Santa Clara University, Santa Clara, CA, USA 
warnings that other countries would soon experience epidemics, but were not sufficiently prepared.

During the last week of February, I gave an interview to a Canadian radio station, and was first asked about people beginning to panic. I responded by explaining that people panic when they experience threats they do not fully understand and where they dread the possible consequences. I pointed out that the novel coronavirus does involve both a lack of understanding and consequences that people dread, a situation I then contrasted with seasonal influenza which does kill thousands of people every year, but does not cause panic. My interviewer then asked me whether I thought the threat from novel coronavirus was real. I responded that indeed I thought it was, and that we would be better off trying to control our emotions so that we might face it sensibly.

My reading of how China had initially confronted the novel coronavirus led me to conclude that its reaction was far from sensible. ${ }^{1}$ China had underreacted ${ }^{2}$; and as I considered the reaction by the U.S. government to the threat to America, I concluded that this country too was underreacting. I made this point in a post I wrote for Forbes, dated March $2 .^{3}$

In mid-March, I read an article authored by Gerd Gigerenzer, entitled "Why What Does Not Kill Us Makes Us Panic."4 The article was dated March 12 and made many important points, not the least being that as we consider future outbreaks, we should be mindful of not forgetting overreactions to past outbreaks. At the same time, Gigerenzer cautioned that only in hindsight will we know if we overreacted or underreacted. I found myself in agreement with all of these points, although by the time mid-March had arrived, I considered it highly likely that both China and the U.S. would be judged as having underreacted at crucial early phases.

Not all countries underreacted to the pandemic. In retrospect, South Korea, Taiwan, and Singapore appear to have responded well. The same goes for Hong Kong, which has a different governance structure from China. Why did policy makers in

\footnotetext{
${ }^{1}$ Buckley, Chris and Steven Lee Myers, 2020. "As New Coronavirus Spread, China's Old Habits Delayed Fight." The New York Times, February 1. https://www.nytimes.com/2020/02/01/world/asia/china -coronavirus.html.

${ }^{2}$ Quite possibly, the most important way in which China underreacted was in failing to recognize that the virus can be spread from one person to another, and that such transmission can occur before the infected party has symptoms. An article by Roach and Shan (2020) provides evidence that Chinese authorities reacted quickly to the situation in December, notified the World Health Organization, which on January 5, 2020 made the information publicly available in a warning post on its website. See Roach, Stephen and Weijian Shan, 2020. "The Fable of the Chinese Whistleblower," Project Syndicate, May 18, 2020. https://www.project-syndicate.org/commentary/trump-charges-against-china-covid19-alter native-facts-by-stephen-s-roach-and-weijian-shan-2020-05?utm_source=Project+Syndicate+Newsl etter\&utm_campaign $=288 \mathrm{cbd} 1 \mathrm{ab} 3$-sunday_newsletter_24_05_2020\&utm_medium $=$ email\&utm term=0_73bad5b7d8-288cbd1ab3-105787773\&mc_cid=288cbd1ab3\&mc_eid=60b6988930.

${ }^{3}$ Shefrin, Hersh, 2020. "Coronavirus Politics Infects U.S. As It Infected China." Forbes, March 2. https ://www.forbes.com/sites/hershshefrin/2020/03/02/coronavirus-politics-infects-us-as-it-infected-china /\#a6cbdb3d8a04.

${ }^{4}$ Gigerenzer, Gerd, 2020. "Why What Does Not Kill Us Makes Us Panic," Project Syndicate, March 12. https://www.project-syndicate.org/commentary/greater-risk-literacy-can-reduce-coronavirus-fear-bygerd-gigerenzer-2020-03.
} 
these centers not underreact? A plausible reason is that all of them had had negative experiences in the past with either SARS or MERS. They learned the hard way, and as a result were much better prepared to deal with a COVID-19 outbreak. Of course, China also had a negative experience with SARS. However, this memory was not strong enough for local officials in Wuhan to react appropriately to the news of a possible new dangerous virus. According to western media, these officials appear to have been more concerned about upsetting their superiors with news that would detract from celebrations associated with Chinese New Year and local Communist party legislatures. ${ }^{5}$

I find the comparison between the number of deaths in Wuhan, New York City, and Hong Kong to be striking. These cities all have roughly population sizes in the same vicinity: Wuhan has approximately 11 million people, New York City has about 9 million, and Hong Kong has about 8 million. In early July 2020, Wuhan had experienced around 3900 deaths, New York City had experienced over 17,500 deaths, and Hong Kong had experienced just 7 deaths. Yes, 7 deaths: that is not a typo. $^{6}$

Underreaction by the policy makers of some countries appeared to reflect excessive optimism. In late February, the U.S. President publicly stated that there was little reason for concern, as the number of U.S. cases was at that time small. In Italy, officials in Milan announced that the city's response to the outbreak would be business as usual, which they communicated with the slogan "Milan does not stop."

Underreaction by other countries, such as the United Kingdom and Sweden, appeared to be more intentional. Although both had observed China's initial underreaction and then aggressive reversal, these countries initially adopted a passive policy, relying only on people washing their hands frequently and properly, and being prudent when interacting with others. The United Kingdom subsequently reversed itself, especially after Prince Charles and Prime Minister Boris Johnson contracted COVID-19. However, Sweden has maintained its passive approach.

An interesting aspect of the initial response by the U.K. government is the involvement of the country's Behavioural Insight Team (BIT), which had initially proposed a passive, voluntary response. The recommendations from BIT reflect concern about "decision fatigue," meaning that people will become fatigued from the self-control it takes to refrain from social interaction. If so, they reasoned, then a lapse in discipline, especially when the number of cases is peaking, might reverse the success from social distancing. Notably, a large number of decision scientists in the U.K. have signed onto a public letter pointing out the absence of evidence for the decision fatigue-based behavior pattern of concern to the BIT unit.

\footnotetext{
${ }^{5}$ See Buckley and Myers (2020) mentioned above.

${ }^{6}$ Lai, Christopher K C Lai, Rita W Y Ng, Martin C S Wong, Ka Chun Chong, Yun Kit Yeoh, Zigui Chen and Paul K S Chan, 2020. "Epidemiological characteristics of the first 100 cases of coronavirus disease 2019 (COVID-19) in Hong Kong Special Administrative Region, China, a city with a stringent containment policy," International Journal of Epidemiology, 2020, 1-10. https://doi.org/10.1093/ije/ dyaa106.
} 
Decision fatigue is a concept embedded in the self-control framework which Richard Thaler and I co-developed in the 1980s. Thaler played a critical role in the founding of the BIT, and therefore it is worth examining his perspective. In a series of tweets, ${ }^{7}$ Thaler writes the following, beginning with the policy to close restaurants as part of a national lockdown strategy.

Same with restaurants. Where are people going to eat instead? Is that better? What will hotel guests do? Will hard-pressed restaurants jump into the delivery system without proper precautions? I don't know. Do you? Does anyone? ... So, not I am not sure that closing schools and restaurants are good or bad policies. I am just asking questions. What I do worry about is that those measures will give us false confidence and delay the important stuff on the medical front ... Our military and organizations like Doctors without Borders can build out emergency medical facilities very quickly. Why aren't we busy doing that in cities that are being hit first? Why aren't we copying best practices from countries that have done well.

These are all important questions, and as far as I can tell, Thaler's views do not provide strong support for the recommendations from BIT favoring a passive response. What I do find interesting is that the chair of the U.S. Senate Intelligence committee was privately discussing the possibility of a military response. National Public Radio reported that the chair commented on the possibility that the military could be mobilized to combat COVID-19, mentioning a military hospital in tents. ${ }^{8}$ He also noted that the decision to do so would belong to the President and Department of Defense. Notably, the chairman's remarks were made to a private gathering. To date, there is no evidence of involvement of the kind described by the U.S. military in addressing the COVID-19 outbreak, thereby providing one more example of diversity of views.

The wide diversity of responses to the COVID-19 pandemic strikes me as one of the intriguing facets of the episode. Certainly the perspective I held before the third week of February 2020 would be consistent with underreaction. If there was a single stimulus that induced me to change my original perspective, it was probably an interview with epidemiologist Bruce Aylward which appeared in the Canadian publication The National Post on February $25,{ }^{9}$ which convinced me that the threat was real and global.

Shortly thereafter, I learned about the diverse responses of two American cities to the Spanish flu a century ago. St. Louis had adopted social distancing while

\footnotetext{
7 See https://twitter.com/R_Thaler/status/1239316132223315968?ref_src=twsrc\%5Egoogle\%7Ctwc amp\%5Eserp\%7Ctwgr\%5Etweet.

8 Mak, Tim, 2020. "Weeks Before Virus Panic, Intelligence Chairman Privately Raised Alarm, Sold Stocks," National Public Radio, Heard on Morning Edition, March 19, 20205:08 AM ET. https://www. npr.org/2020/03/19/818192535/burr-recording-sparks-questions-about-private-comments-on-covid-19.

9 Bharti, Bianca, 2020. "Coronavirus updates: Top Canadian epidemiologist fears world not prepared for global outbreak: Bruce Aylward says countries should be looking to China for expertise in how to manage and treat the disease now known as COVID-19." National Post Wire Services, February 25. https:// nationalpost.com/news/world/coronavirus-live-updates-covid-19-italy-wuhan-china-canada-deaths.
} 
Philadelphia had not, with the result that deaths were much higher in Philadelphia. ${ }^{10}$ After 24 weeks of the pandemic, as the pandemic was coming to an end, Philadelphia had 748 deaths per 100,000, while St. Louis had 358. That difference implied to me that Philadelphia had severely underreacted to the outbreak of Spanish flu.

Why is it that a century later, some, like South Korea and Hong Kong, followed in the tradition of St. Louis, while others such as the United Kingdom, Sweden, ${ }^{11}$ and the United States followed in the tradition of Philadelphia, at least in respect to their initial responses?

At its heart, is diversity simply a manifestation of Darwinian principles? Is that why policy makers, and for that matter academics and others, have exhibited such diversity in their responses to the outbreak of COVID-19?

Darwin taught that species survive through their ability to mutate. When the environment changes dramatically, nature selects a mutation that happens to be well matched to the altered environment. At its core, is that why the responses to pandemics are diverse, so that at least someone, somewhere responds appropriately?

Whatever the answer, the novel coronavirus is known to be mutating, putting Darwin's principles into effect, which increases the challenge to humans of creating a vaccine that will lead to its eradication.

\section{Compliance with ethical standards}

Conflict of interest I have no conflict of interest to report.

Publisher's Note Springer Nature remains neutral with regard to jurisdictional claims in published maps and institutional affiliations.

\footnotetext{
10 Strochlic, Nina and Riley Champine, 2020. "How some cities 'flattened the curve' during the 1918 flu pandemic.” National Geographic. https://www.nationalgeographic.com/history/2020/03/how-cities-flatt ened-curve-1918-spanish-flu-pandemic-coronavirus/\#close.

11 Policy makers in Sweden appear to recognize having underreacted. See Pancevski, Bojan, 2020. "Coronavirus Is Taking a High Toll on Sweden's Elderly. Families Blame the Government." The Wall Street Journal. Updated June 18, 2020 11:19 am ET. https://www.wsj.com/articles/coronavirus-is-takin g-a-high-toll-on-swedens-elderly-families-blame-the-government-11592479430.
} 